\title{
The Ukraine: In Search \\ of Submerged Late Palaeolithic Sites on the North-Western Black Sea Shelf
}

\author{
Sergey Kadurin, Valentina Yanko-Hombach, \\ and Olena Smyntyna
}

\begin{abstract}
The continental shelf offshore of the Ukraine coast represents one of the largest areas of submerged landscape in the Black Sea, comparable to the extensive shelf areas of Northwest Europe. The general region has a long history of Palaeolithic occupation and numerous archaeological sites associated with the major river systems draining from the north, including many famous Palaeolithic settlements. The submerged landscape exposed during periods of low sea level would have offered an extensive and attractive extra increment of land. Underwater archaeological survey in the Black Sea has so far failed to produce convincing evidence of pre-Holocene sites, but the expectation that
\end{abstract}

\section{S. Kadurin}

Department of Engineering Geology and

Hydrogeology, Odessa I.I. Mechnikov National

University, Odessa, Ukraine

V. Yanko-Hombach ( $\bowtie)$

Department of Physical and Marine Geology, Odessa

I.I. Mechnikov National University, Odessa, Ukraine

Avalon Institute of Applied Science,

Winnipeg, MB, Canada

e-mail: valyan@onu.edu.ua;

valyan@avalon-institute.org

O. Smyntyna

Department of Archaeology and Ethnology of

Ukraine, Odessa I.I. Mechnikov National University,

Odessa, Ukraine

e-mail: smyntyna_olena@onu.edu.ua the Ukrainian shelf harbours Late Upper Palaeolithic sites is strengthened by the presence of occasional flint artefacts in sediment cores recovered from the shelf area during geological surveys. This chapter develops a predictive model for identifying target areas in the search for Late Palaeolithic sites on this submerged landscape. We focus on the Dniester-Kuyalnik region and analyse the location and distribution of on-land Late Palaeolithic sites in relation to the topographic and palaeoenvironmental features of their local surroundings to identify key determinants of site location. We then use the maps produced by the many hundreds of sediment sequences recovered by drilling and coring on the shelf, many radiometrically dated, to identify similar features on the submerged landscape. We also assess the likelihood of site preservation and visibility under different scenarios-rapid or gradual-of sea-level rise. A preliminary test of the model was attempted with remotely operated vehicles, video and acoustic equipment, but was terminated prematurely by logistic problems, and further investigation awaits improved funding.

\section{Keywords}

Sea-level change Coastline migration . Human adaptation · Palaeolithic $\cdot$ Holocene Underwater survey 


\subsection{Introduction}

The Ukrainian continental shelf exposed as a sub-aerial landscape at the maximum lowering of sea level at the Last Glacial Maximum represents one of the largest areas of now-submerged landscape in the Black Sea (Fig. 21.1), and one of the largest in Europe apart from the North Sea (see also Bailey et al., Chap. 1, Fig. 1.1, this volume; Peev et al., Chap. 20, this volume). Palynological data show that this new territory was a steppe region that could have been exploited extensively by hunter-gatherers migrating in from west to east and from the north-west to the south (Stanko 2007; Yanko-Hombach et al. 2011a, b).

Many Upper Palaeolithic archaeological sites are present in these source regions, extending from Romania through the Ukraine to the Crimea, particularly in the basins of the major rivers draining into the Black Sea from the north such as the Dniester and the Dnieper (Yanko-Hombach et al. 2017, Figure 16.24). Notable examples are Movileni, Lespezi, Mitoc-Malul Galben and Dobrudja in Romania, Molodova in the Middle Dniester region, Liubymovka in the Lower Dnieper in the Ukraine and Siuren 1 and Vishenne 2 in Crimea; (Otte et al. 1997; Demidenko 20002001; Chabai 2007). The similarities in stone tool assemblages between these sites suggest a high degree of mobility and connectivity over wide areas.

Moreover, several flint tools have been retrieved from boreholes in various places on the north-western shelf (Stanko 2007, p. 374). In fact, flint pebbles and splinters were mentioned during description of samples recovered from geological survey. However, these descriptions were made by geologists who lacked the knowledge to distinguish between natural pieces of flint and artefacts.

All these factors suggest a high likelihood that the new land exposed by lowered sea level would

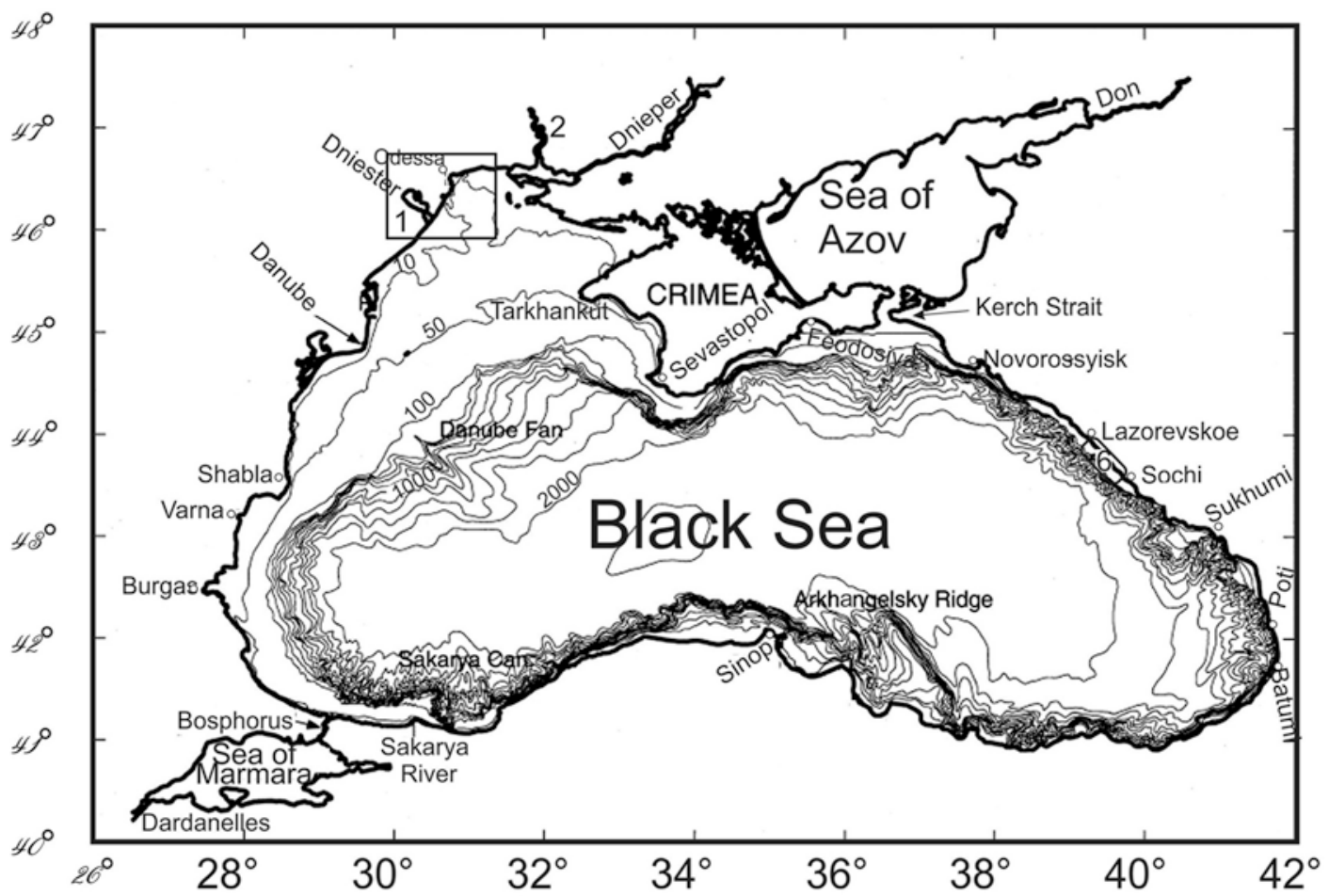

Fig. 21.1 Map of the Black Sea and adjacent regions, showing the extent of the shelf areas, the connections to the Marmara and Aegean seas via the Bosphorus and Dardanelles Straits and the location of the case study area. (1) The Dniester Estuary region; (2) The Berezan Estuary region. From Yanko-Hombach et al. 2017 
have provided a very significant and productive extension of new territory attractive to human settlement. This possibility was explicitly recognised over a decade ago by Stanko (2007) who, in writing about the north-western Black Sea shelf, noted:

Fluctuations in sea level and the commensurate shrinking and expansion of littoral areas had considerable impact on the settlement pattern of the final Palaeolithic and Mesolithic societies there. (Stanko 2007, p. 372)

Archaeological surveys targeted at final Palaeolithic and Mesolithic sites on the northwestern Black Sea shelf and along the submerged river valleys might be deemed promising... Such ... survey ... might solve a number of major problems related to the character and chronology of the submergence, migrations, and the interrelationship between prehistoric groups of the Balkans, Central Europe, and Crimea. (Stanko 2007, p. 374)

Until recently, there has been little opportunity to pursue these ideas. Blavatsky (1972) provided the first English language review of underwater archaeological studies in the Black Sea, describing submerged Greco-Roman ruins at water depths of 4-8 m near the Azov Sea entrance and in Taman Bay, near Phanagoria. Similar submerged historical archaeological sites were found in the Bug River Estuary, Olbia Pontica (Kryzhitskiy et al. 1999) in the Dniester Estuary, ancient Tyras (Samoilova 1988) and off the south-eastern Crimean Peninsula (Bolikhovskaya et al. 2004). None of these studies reported any submerged prehistoric settlements.

Dimitrov and Dimitrov (2004) reviewed underwater archaeological studies related to a 'Varna culture' that appeared near the present-day coast of Bulgaria around 5000 BC. Drowned settlements in Lakes Durankulak and Varna were dated to 5270 BC (Dimitrov and Dimitrov 2004, p. 49) by correlation with dated settlements on the lake shore. They claimed that 'Before the Flood [about 7600 years ago], Neolithic people inhabited not only today's coast but also that part of the bottom (called the shelf) which was land' (Dimitrov and Dimitrov 2004, p. 51). So far, however, drowned prehistoric archaeological sites have been found only close to the present Black Sea shore of Cape
Shabla north of Varna and in Lake Varna in water less than 10 m deep (Peev 2009). The Shabla site was indirectly dated to the Late Neolithic (Eneolithic) by correlation with the sea-level curve of Peychev and Peev (2006), and submerged settlements in the coastal Varna-Beloslav Lake were indirectly dated to the Late Eneolithic and Early Bronze Age (Peev 2009, 91; see also Peev et al., Chap. 20, this volume).

Coleman and Ballard (2007, p. 677) reviewed evidence for submerged palaeoshorelines in the southern and western Black Sea and their implications for prehistoric inundation. Despite clusters of Neolithic to Bronze Age sites near the present coastline, evidence of prehistoric occupation at water depths greater than $10 \mathrm{~m}$ is restricted to one ceramic plate of debatable Neolithic age from $-90 \mathrm{~m}$ off Varna, and photographs of boulders at $-90 \mathrm{~m}$ depth off Sinop, possibly related to human habitations along a shoreline inundated during the Neolithic over 8000 years ago (Ballard et al. 2001). In fact, underwater artefacts and shipwrecks recovered to date from this region are of historical age (Ward and Ballard 2004; Ward and Horlings 2008). However, Algan et al. (2009) found archaeological remnants of a Neolithic culture in Istanbul dating between 8400 and 7300 cal BP, indicating shoreline occupation when sea level was $6 \mathrm{~m}$ lower than today. These archaic Fikirtepe pottery sherds are immediately overlain by Early Iron Age artefacts, dated by molluscs from 3335 to 3260 cal BP.

Thus, despite decades of searching for submerged prehistoric habitations, there have been no definite finds below a water depth of $-10 \mathrm{~m}$, and reports of Neolithic settlements (e.g., Ballard 2001) are based on debatable Early Holocene sealevel estimates (Yanko-Hombach et al. 2011a, b). However, the region is extremely rich in archaeological sites and information relating to the history of sea-level change and the geomorphology and palaeoenvironment of the continental shelf, thanks to systematic studies that have been carried out by several generations of Soviet, Russian and Ukrainian researchers. Discussions have been further intensified during the past decade by a series of multidisciplinary and international research networks involving the increasing participation of 
western scholars and focussed on Black Sea sealevel change, shoreline dynamics at the Pleistocene-Holocene boundary, their implications for understanding global climate change and their relationship to transformations in human occupation systems, subsistence strategies and stone-tool technologies (Yanko-Hombach and Smyntyna 2009; Yanko-Hombach et al. 2011a, b, 2014; Lericolais 2017; Yanko-Hombach 2017; Yanko-Hombach et al. 2017). ${ }^{1}$

The main goal of this chapter is to identify potential locations for submerged prehistoric sites and landscapes on the north-western Black Sea shelf using the on-land archaeological data as a basis for prediction. Here we:

1. Look for regularities in the spatial distribution of prehistoric sites and artefacts known today in the on-land archaeological record.

2. Examine geomorphological, geological and climatic data to identify the environmental features associated with the locations of these prehistoric sites.

3. Develop a predictive model, based on (1) and (2) for locating submerged prehistoric sites and provide some evaluation of the conditions in which they are likely to have survived the potentially destructive effects of sea-level rise.

\subsection{Case Study Area}

The Dniester-Kuyalnik interfluve, including both on-shore and underwater areas, was chosen as the case study area (Fig. 21.1). The area is well studied geologically and geomorphologically and has a high density of Late Palaeolithic sites supplemented by geographic coordinates and extensive field studies (Table 21.1). The area is located within the third alluvial terrace of the Dniester River, is crossed by valleys of small rivers (e.g. the Baraboy) and contains the system of valleys associated with the Sukhoy Liman (an ancient estuary) as well as good-quality and well-exposed flint outcrops (Sibirchenko et al. 1983).

\footnotetext{
${ }^{1}$ See the Acknowledgements for full details of these research networks.
}

\subsection{Materials and Methods}

There are about 250 known Late (Upper) Palaeolithic archaeological sites in the southwestern part of the Ukraine (Yanko-Hombach et al. 2011a, b, Figure 7). They comprise mainly Aurignacian industries (32-24 ka; Anikovich et al. 2007) and Epigravettian (19-12 ka; Zaliznyak 2014). More than 30 of them were discovered on the present-day on-shore segment of the case study area (Table 21.1).

Each site has GPS coordinates and a short geographic designation enabling one to place it on a geomorphological map (Fig. 21.2). The map is based on information from hundreds of gravity cores and drill holes with lengths up to 5 and $100 \mathrm{~m}$, respectively, many of which were dated by radiometric methods. Descriptions of the main cores and geological maps and reports in digital format are available at http://geoinf.kiev.ua/ and http://geoinf.kiev.ua/wp/kartograma.htm.

In order to increase the probability of finding submerged archaeological sites on the shelf, a method with clearly defined topographic, palaeogeographical and geological search criteria was implemented. These criteria are designed to identify topographic positions that have a good overview of the terrain, nearby freshwater sources and exposures of flint material for stone tool manufacture, a combination of qualities we think would have been influential in site selection.

To further narrow the search, we used GIS software to reconstruct the size of a typical site catchment or site territory based on the distance between site clusters but without taking account of topographic irregularities and barriers (see, e.g. Bailey and Davidson 1983).

\subsection{Results}

\subsubsection{Palaeogeography and Site Prediction}

Geomorphologically, the study area includes a watershed plateau, river terraces and slopes, river valleys and hills (Fig. 21.2). The watershed plateau is represented by a Pleistocene succession of 
Table 21.1 List of archaeological sites and artefacts with coordinates, geographical location and archaeological age based on Kurten (1969), Sinitsyn (1997, p. 58), Sapozhnikov and Sapozhnikova (2011, table 4, pp. 39-43), Dodonov et al. (2000, p. 307), Djindjian et al. (2006) and Stanko (1999)

\begin{tabular}{|c|c|c|c|c|c|c|}
\hline Site no & Site name & Type & Latitude & Longitude & Geographic location & Age yrs. ago \\
\hline 1 & Cobruciu & Artefact & 46.6622 & 29.7578 & Dniester & $14,000-12,000$ \\
\hline 2 & Varvara I & Artefact & 46.7728 & 29.9689 & Kuchurgan & $18,000-12,000$ \\
\hline 3 & Calfa & Artefact & 46.9072 & 29.4558 & Dniester & $18,000-16,500$ \\
\hline 4 & Bolshaya Akkarzha & Site & 46.3425 & 30.6095 & Velykodolynskoe & $19,000-17,000$ \\
\hline 5 & Anetovka II & Artefact & 47.7039 & 31.1222 & Bakshala & $19,100-18,000$ \\
\hline 6 & Anetovka I & Artefact & 47.7069 & 31.1636 & Bakshala & $19,500-19,100$ \\
\hline 7 & Tatarbunary & Site & 45.8572 & 29.6562 & Koghylnik & $20,000-12,000$ \\
\hline 8 & Bolshaya Akkarzha II & Site & 46.3343 & 30.6066 & Velykodolynskoe & $22,000-18,000$ \\
\hline 9 & Bolshaya Akkarzha III & Site & 46.3264 & 30.6040 & Velykodolynskoe & $22,000-18,000$ \\
\hline 10 & Gribovka & Site & 46.1944 & 30.5576 & Baraboy & $22,000-20,000$ \\
\hline 11 & Gribovka I & Site & 46.2004 & 30.5498 & Baraboy & $22,000-20,000$ \\
\hline 12 & Otarik & Site & 46.3321 & 30.3376 & Sukhoy Liman & $22,000-20,000$ \\
\hline 13 & Skurta & Site & 46.3321 & 30.3376 & Sukhoy Liman & $22,000-20,000$ \\
\hline 14 & Roxolany & Site & 46.1628 & 30.4736 & Dniester & $24,000-20,000$ \\
\hline 15 & Caragas & Artefact & 46.7881 & 29.6597 & Dniester & $24,000-20,000$ \\
\hline 16 & Anetovka XXII-1989 & Artefact & 47.7183 & 31.1764 & Southern Bug & $24,000-20,000$ \\
\hline 17 & Anetovka XXI & Artefact & 47.7186 & 31.1811 & Southern Bug & $24,000-20,000$ \\
\hline 18 & Baraboy 3 & Site & 46.2020 & 30.5765 & Baraboy & $25,000-22,000$ \\
\hline 19 & Baraboy 2 & Site & 46.2110 & 30.5548 & Baraboy & $25,000-22,000$ \\
\hline 20 & Efymovka & Site & 46.3605 & 30.3454 & Dniester & $25,000-22,000$ \\
\hline 21 & Efymovka2 & Site & 46.3516 & 30.3466 & Dniester & $25,000-22,000$ \\
\hline 22 & Nikolaevka II & Site & 46.3321 & 30.3376 & Dniester & $25,000-22,000$ \\
\hline 23 & Peshcera Nordmana & Site & 46.4792 & 30.7345 & Black Sea & $28,000-26,000$ \\
\hline 24 & Novaya Doina & Site & 46.3321 & 30.3376 & Sukhoy Liman & $32,000-11,000$ \\
\hline 25 & Olanesti & Artefact & 46.4975 & 29.9675 & Dniester & $32,000-12,000$ \\
\hline 26 & Krasnaya Kosa & Artefact & 46.3475 & 30.0953 & Dnestrovsky Liman & $32,000-12,000$ \\
\hline 27 & Kazatskoe & Artefact & 46.3533 & 30.0953 & Dnestrovsky Liman & $32,000-12,000$ \\
\hline 28 & Turlaki & Artefact & 46.1992 & 30.2331 & Dnestrovsky Liman & $32,000-12,000$ \\
\hline 29 & Roxolany & Artefact & 46.1622 & 30.4747 & Dnestrovsky Liman & $32,000-12,000$ \\
\hline 30 & Otaryk & Artefact & 46.2061 & 30.4208 & Dnestrovsky Liman & $32,000-12,000$ \\
\hline 31 & Aneovka XIII & Artefact & 47.7200 & 31.1764 & Bakshala & $32,000-24,000$ \\
\hline 32 & Bornatove-zatoka & Site & 46.7756 & 30.4909 & Khadzhybey & $32,000-26,000$ \\
\hline 33 & Zeleny Khutor & Artefact & 46.5006 & 30.1733 & Kuludorova & $32,000-28,000$ \\
\hline 34 & Kuludar & Artefact & 46.5008 & 30.2033 & Kuludorova Balka & $32,000-28,000$ \\
\hline 35 & Tatarka 2 & Site & 46.4067 & 30.5907 & Dalnik & $34,000-22,000$ \\
\hline
\end{tabular}

alternating aeolian-deluvial, aeolian and eluvial rocks forming loess loams with buried soils up to $40 \mathrm{~m}$ in thickness (Avrametz et al. 2007).

The slopes of the river valleys mainly comprise alluvial sediments accumulated on 12 Quaternary terraces of the rivers flowing into the Black Sea (Veklich and Sirenko 1976; Veklich et al. 1993; Sibirchenko et al. 1983; Ivanov 1987; Shmuratko 2001). One place where all 12 terraces are exposed is the lower reaches of the Dniester River. The deposits of the terraces are basically similar in their lithological characteristics, being represented by sands with pebbles in the lower part and sandy silts and clays, sometimes peat, in the upper part. However, there are some differences in the composition of the heavy mineral fraction caused by differences in the redistribution of eroded sedimentary material. The most significant variations are present within the third terrace, where numerous exposures of abundant, good-quality flint are present (Veklich and Sirenko 1976; Veklich et al. 1993). 


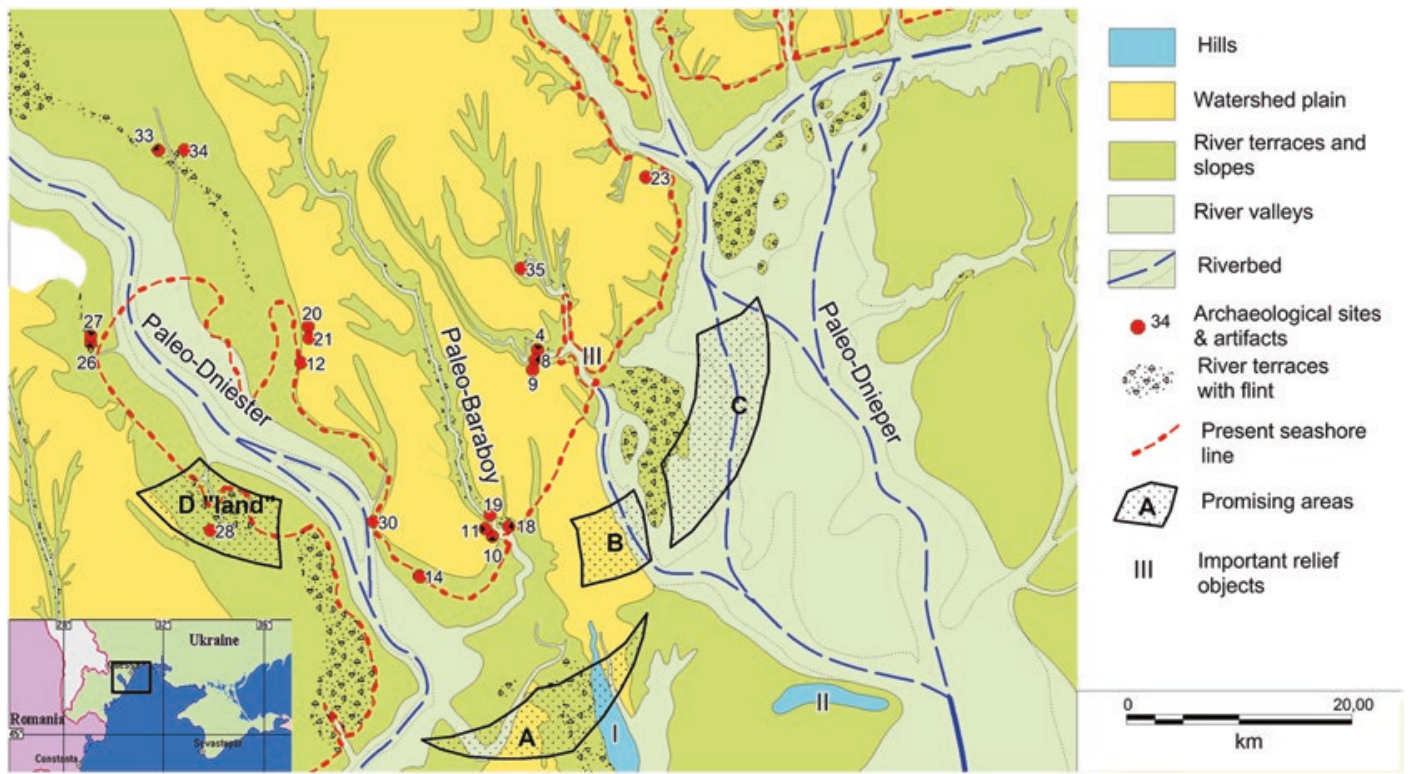

Fig. 21.2 Geomorphological map of the pre-Holocene (largely Late Pleistocene) geology, produced at scales ranging from 1:200,000 to 1:50,000. Data from quadrants L-36-XIII and L-36-XIV mapped by Prichernomor SRGE [Black Sea Area State Regional Geologic Enterprise] (www.pgrgp.com.ua; Podoplelov et al. 1975; Karpov et al. 1978; Sibirchenko et al. 1983; Gozhik et al. 1987; Avrametz et al. 2007, see also Yanko-Hombach et al. 2017, Fig. 16.3). The map shows locations of on-land Late Palaeolithic sites and artefacts together with underwater areas that appear promising for locating submerged Late Palaeolithic sites according to the predictive model. See text and Fig. 21.3 for further detail and discussion

Valley bottoms are filled with typical floodplain sediments, such as interbedded sandy silt, clay and peat.

The hills, such as the Dnestrovsky (I) and Katranya (II) Banks, are formed of Upper Pleistocene marine sediments of Karangatian age-MIS 5e, 74-123 ka BP (Yanko-Hombach and Motnenko 2016a, b). Lithologically, they are represented by cemented sandy coquina (limestone with shells) that was exposed during the post-Karangatian regression, passed the first stage of lithification in a coastal environment and formed positive relief forms with a cemented crust over the underlying loose sediments. During the Holocene transgressions, these hills became underwater banks.

All analysed sites are located on the alluvial terraces of secondary rivers or tributaries and form small groups or clusters, each of which includes two to four sites (Fig. 21.3a). The distance between clusters is typically within the range of a 1-day walk (Fig. 21.3b). The distribu- tion of these distances follows a normal probability (Gaussian) curve (Fig. 21.3c) with an average value of $19.49 \mathrm{~km}$ and a standard deviation of $6.51 \mathrm{~km}$ (95\% confidence interval). Moreover, these sites are broadly contemporaneous, suggesting that their distribution reflects a real pattern of prehistoric land use and that the factors that determine the location of the site clusters are concentrations of attractive resources and a distance to the nearest neighbouring cluster that creates a suitably sized territory large enough to support each cluster. It is possible that some sites are missing because they have not been preserved or discovered, but the region has been well studied and the distribution of known sites is clearly not random.

The boundary values (maximum and minimum inter-cluster distances) are $16.74 \mathrm{~km}$ and $22.24 \mathrm{~km}$. If these distances are accepted as maximum and minimum spacings between clusters, then a predictive model can be created by drawing concentric circles with these radii around 

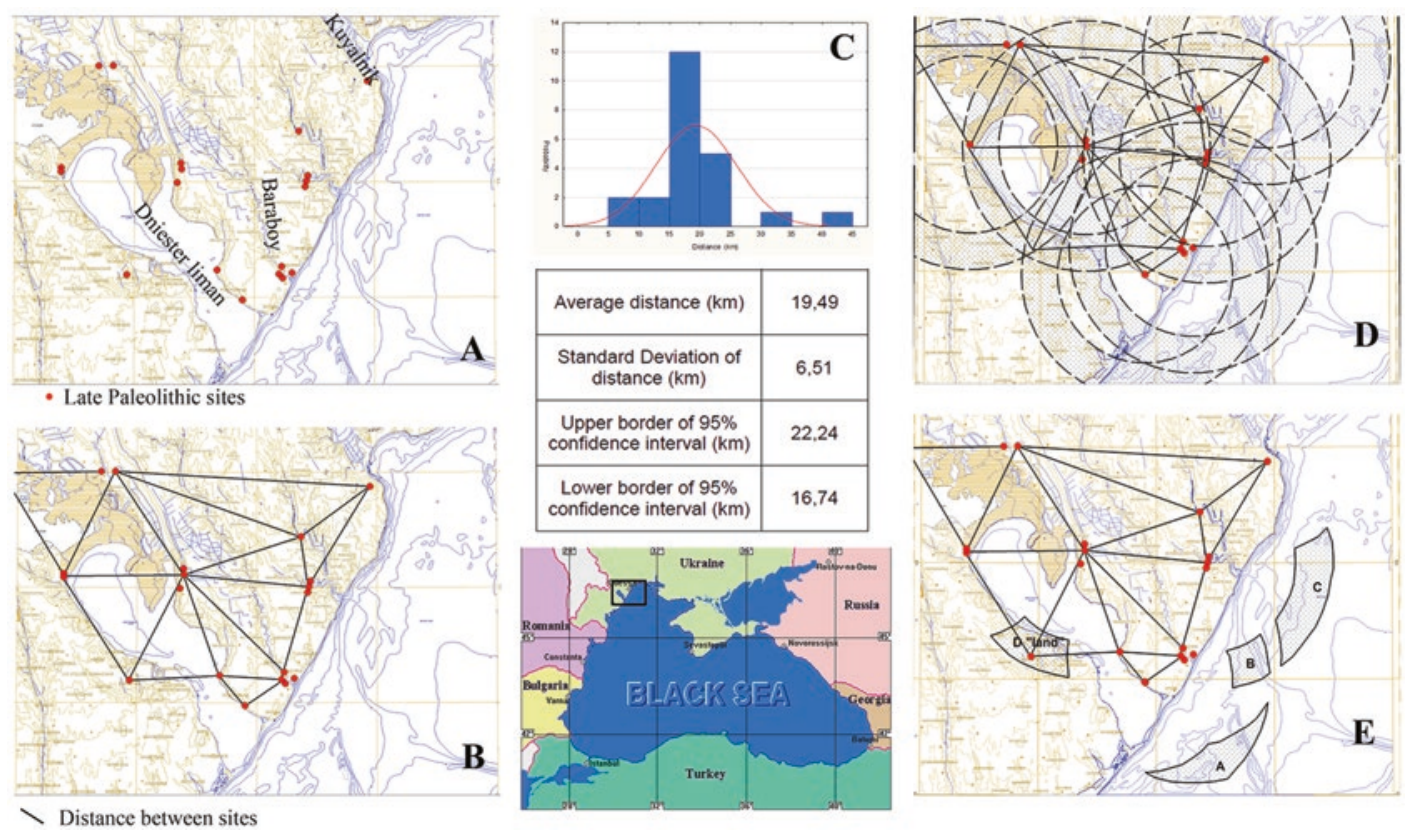

Fig. 21.3 Geostatistical predictive model for identifying target areas to search for submerged Late Palaeolithic sites in the case study area. (a) Location of known Late Palaeolithic sites on-land and within the main river valleys today; (b) distance between clusters of sites; (c) histogram of distances showing normal (Gaussian) type of distribution; (d) modelling of concentric catchment circles based on maximum and minimum inter-cluster distances (95\% confidence interval); (e) areas that lie at the intersections of catchment circles and could therefore be promising targets in the search for submerged Late Palaeolithic sites

each site cluster. The circles then map out a catchment within which known sites are located in the centre and other possible sites would lie within the inner and outer radii corresponding to these values (Fig. 21.3d). Based upon inter-site distances exhibited by known sites, the intersection areas of these catchment circles would be the most promising in the search for new clusters of sites (Fig. 21.3e). Overlain on a geomorphological map of the study area (Fig. 21.2), these intersection areas (A, B, C, D in Figs. 21.2 and 21.3e) show possible locations of submerged archaeological sites that satisfy the search criteria.

\subsubsection{Underwater Target Areas}

There are three intersection areas (Fig. 21.2) that could be suitable for our purpose. The first one (A) is located $9 \mathrm{~km}$ from the present coastline at water depths of 15-20 m bsl (below sea level) in front of the present spit of the Dniester Estuary.
Here all search criteria converge. There are small rivers flowing into the large Dniester River forming bluffs and terraces with a good overview of the surrounding terrain. The main elevation point is the Dniesterovsky Bank, which would have been a hill rising above the surrounding plain during Late Palaeolithic time. There are exposed outcrops of good-quality flint material in significant quantity, and according to geostatistical data, the location is at the appropriate distance from the nearest cluster of known sites. Area A seems quite promising in the search for submerged Late Palaeolithic sites.

The second area (B) is located $7 \mathrm{~km}$ from the modern coastline opposite Sandzeika village at a water depth of 20-22 m (Fig. 21.2). In the Late Palaeolithic, there was a system of small rivers with elevated bluffs and terraces (terrace III). These rivers in recent times formed the Sukhoy Liman. From the elevated points, there was a good view to the other side of the river valley as well as to the confluence of these tributaries with 
the Palaeo-Dnieper valley. The river terraces contain numerous outcrops of exposed flint material (Sibirchenko et al. 1983). The distance of area B from other archaeological sites also fits the predictive model.

The third area (C) is located directly within the Palaeo-Dnieper River valley at $25 \mathrm{~m}$ (Fig. 21.2). None of the search criteria (except close proximity to flint) is satisfied here. For example, there was no prominent elevated area, the flat sides of the large valley were wetlands (indicated by the presence of peat deposits), and flint nodules are small and poor in quality. As such, this area is not considered as promising in the search for submerged Late Palaeolithic sites. There is one more area D (Fig. 21.2) located presently on the left side of the Palaeo-Dniester River at $2 \mathrm{~m}$ asl (above sea level). This area might be promising for the discovery of on-land archaeological sites.

\subsection{Discussion}

Three areas, A, B and C, described above (Fig. 21.2) seem to be promising for finding submerged Late Palaeolithic archaeological sites at water depths of 20-22 m. Could these sites be present below sea level and if so when were they inundated? To answer this question, the dynamics of sea level, climate and salinity variation during the Late Palaeolithic period should be considered using geological, palynological and palaeontological data together with archaeological evidence of human adaptive strategies. This may give us further clues as to whether we are correct in our assumptions regarding the search for submerged Late Palaeolithic sites.

\subsubsection{Sea-Level Change and Palaeoenvironment}

In terms of chronology, the Late Palaeolithic corresponds approximately to the following stratigraphic units: the Tarkhankutian (c. 44-32 ka cal BP) and the Lower (c. 32-20 ka cal BP) and Upper Neoeuxinian (c. 20-11.5 ka cal BP) beds (Yanko-Hombach 2007; Yanko-Hombach et al.
2014). The Tarkhankutian beds are occasionally recovered in cores (Fig. 21.4) penetrating below the 30-35 m isobath. The Tarkhankutian basin was a brackish (8-11 psu) body of water, $30 \mathrm{~m}$ below present sea level, and connected with the Mediterranean Sea (Nevesskaya 1965; YankoHombach 2007; Yanko-Hombach et al. 2017). Located to the south of the continental glaciers, the northern Black Sea coastal region provided favourable conditions for intensive settlement and hunting, as evidenced by the presence of such large settlements as Sagaidak 1 and Anetovka 1 (Yanko-Hombach et al. 2011a, b).

The Lower Neoeuxinian beds deposited during the LGM are distributed everywhere in the Black Sea below the $100 \mathrm{~m}$ isobath (Fig. 21.4) (Kvasov 1975; Fedorov 1977, 1978, 1988; Shcherbakov et al. 1978; Abashin et al. 1982; Shcherbakov 1983; Shnyukov 1985; Svitoch et al. 1998; Kuprin 2002; Kuprin and Sorokin 2007; Yanko-Hombach 2007; Yanko-Hombach et al. 2014, 2017; Harff et al. 2016). During that time, the Black Sea was a brackish lake with salinity around 5 psu and a level at $-100 \mathrm{~m}$. The lake was isolated from both the Caspian and Mediterranean seas (Kuprin and Sorokin 2007; Yanko-Hombach 2007; Yanko-Hombach et al. 2011a, b, 2014, 2017). A large portion of the present shelf above the $100 \mathrm{~m}$ isobath was exposed and eroded. The north-western shelf was downcut some $40 \mathrm{~m}$ to the basement by the PreDanube, Pre-Dnieper and Pre-Dniester rivers and covered by subaerial loams (e.g. Shcherbakov et al. 1978; Shcherbakov 1983; Inozemtsev et al. 1984; Fedorov 1988). River mouths were relocated 80-100 km seaward (Gozhik 1984; Shnyukov 1985), where they possessed poorly developed deltas and opened directly into canyons on the continental slope (Fig. 21.5; YankoHombach et al. 2017).

At the LGM, the entire Eastern European platform was covered with periglacial tundra-steppe vegetation (Artyushenko 1970; Artyushenko et al. 1972; Mudie et al. 2014). Extremely harsh climatic conditions caused the displacement of the late Palaeolithic inhabitants from Central and Eastern Europe to the northern Black Sea coastal regions (Yanko-Hombach et al. 2011a, Figure 6). 


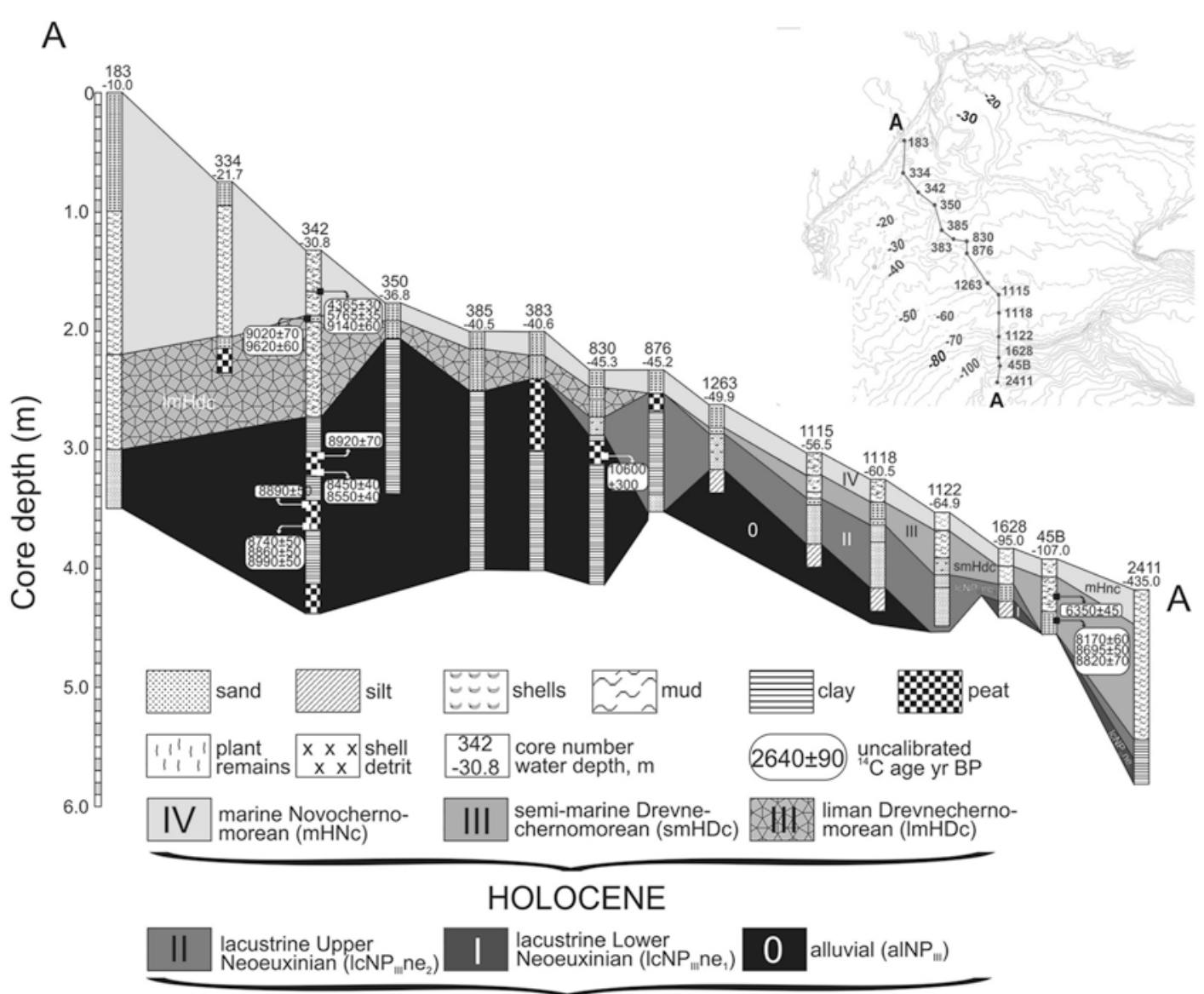

NEOPLEISTOCENE

Fig. 21.4 Palaeo-Dniester valley cross-shelf profile, showing sediment lithology and genetic type, depositional setting and stratigraphic ages. Inset shows shelf bathymetry, locations of transect cores and present-day estuaries at the seaward end of the Dnieper, Bug and Dniester rivers. Shell detrit = detrital shell fragments. Profile is based on results of a 1:200,000 marine geological survey. From Yanko-Hombach et al. 2014, 2017

In fact, the Black Sea steppes represent a natural refuge for the populations of the contiguous territories, which is reflected in the mosaic of modern ethnic groups in the region and confirmed by the highest population densities in Eastern Europe (Yanko-Hombach et al. 2011a, Figure 7). In search of protection from the harsh conditions of the periglacial regions and the need to find animals for hunting, bison hunters moved to the south and south-west along the river valleys of the Dnieper, the Southern Bug, the Dniester and the Prut and reached the shore of the Early Neoeuxinian lake. However, it is unlikely that they settled along the immediate coastline. Palynological data from high-resolution marine cores suggest a marshy and mosquito-infested shoreline subject to periodic river flooding (Mudie et al. 2002, 2007). This might have provided good hunting and fishing but poor conditions for the location of settlement because of brackish water and soils prone to salinization and waterlogging. This is consistent with the evidence that prehistoric populations preferred to settle in small river valleys. These marshy conditions may have been inhospitable for permanent settlement, but there is no evidence that prehistoric people would have avoided coastal locations on the Black Sea because of the presence of saltwater (Yanko-Hombach et al. 2014). 


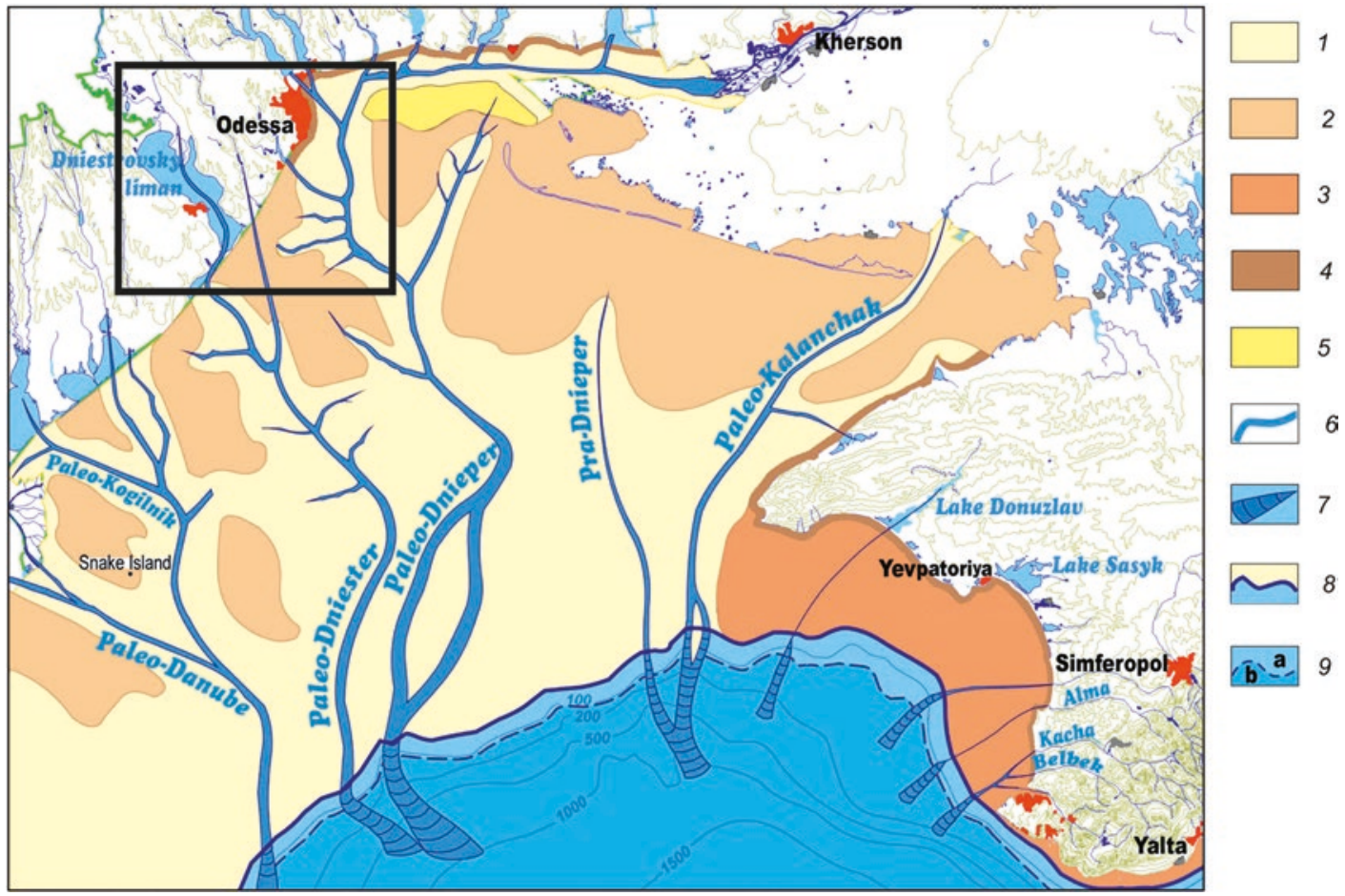

Fig. 21.5 Schematic geomorphological map of the north-western shelf during the Early Neoeuxinian: (1) Palaeovalleys and large alluvial plains; (2) gently sloping hills formed by Late Pleistocene marine and continental landforms; (3) gently sloping piedmont uplands; (4) steep banks and seabed folded bedrock; (5) large relict accumulative landforms formed by sand; (6) palaeoriver bed; (7) underwater debris cone; (8) coastline of $18 \mathrm{ka} \mathrm{BP;} \mathrm{(9)} \mathrm{shelf} \mathrm{edge,} \mathrm{(a)} \mathrm{outer}$ shelf, (b) continental slope. From Yanko-Hombach et al. 2017

These changes of environmental conditions in the north-western Black Sea region resulted in the emergence of a new occupation system based on the collective hunting of bison herds, which involved the short-term concentration of human groups at specialised base camps, designed for implementation of economic activities connected with the preparation for a major hunt and further celebration of its results, and a set of other sites briefly visited during the rest of the year. This occupation strategy is particularly well demonstrated by the key archaeological sites of the region belonging to the Epigravettian, notably Anetivka 2 (on the Southern Bug River). Within walking distance of this site, there are over 30 Late Palaeolithic archaeological sites, all within reach of the Bakshala River, a tributary of the Southern Bug (Stanko 1999, p. 322; Stanko 1997, Figure 23).
The Lower Neoeuxinian beds are often overlapped by sub-aerial loams and later by aquatic sediments with freshwater ostracods Candona and Candoniella indicating the transformation of bottom conditions from an erosional to a subaquatic accumulative phase at the beginning of the Late Neoeuxinian transgression (Gozhik 1984; Shnyukov 1985).

The Upper Neoeuxinian beds cover the Black Sea floor almost everywhere on the north-western shelf below the 37-39 m isobath (Fig. 21.4; Larchenkov and Kadurin 2011; Mudie et al. 2014; Yanko-Hombach et al. 2014, 2017). Palaeosalinity for the Late Neoeuxinian lake was about 5 psu in shallow areas and could have reached 7 psu and even 12 psu in deeper parts of the basin (Nevesskaya 1965; Mudie et al. 2001; Mudie et al. 2011; Marret et al. 2009; YankoHombach et al. 2014, 2017). Despite a relatively 
high salinity, Mediterranean species are absent, and Caspian immigrants are abundant.

Prevalence of broad-leaved trees (e.g. Quercus, Carpinus, Ulmus, Salix, Betula) over conifers (e.g. Pinus) and grasses in the sporepollen diagrams indicates that climate became warmer compared to the Early Neoeuxinian (Pop 1957; Bozilova 1975). During the Late Neoeuxinian transgression, a relatively wide and shallow, sub-horizontal inner shelf with depths of c. $10-15 \mathrm{~m}$ was formed. Due to an increase in the base level and consequent increased lateral erosion, the river valleys expanded due to bank scouring, and the accumulation of alluvium intensified. The absence of Mediterranean organisms clearly shows the lack of connection with the Mediterranean Sea. The widespread presence of Caspian species indicates a possible connection with the Caspian Sea. It is also possible that under favourable conditions Caspian species could expand from sheltered habitats in river mouths and lagoons, as was noted by Nevesskaya (1965). The Caspian waters, together with strong freshwater runoff from the land, raised the level of the Late Neoeuxinian lake by $70 \mathrm{~m}$ within 3-4000 years. In many places, the Upper Neoeuxinian beds are overlain by peat (Fig. 21.4) with an age of $\sim 11.7 \mathrm{ka}$ cal BP (10 ka radiocarbon years BP) and/or coarse sediments. Their maximum depth of deposition does not exceed $50 \mathrm{~m}$. These peats were formed during the Younger Dryas around $11.7 \mathrm{ka}$ cal BP when the level of the lake dropped to $55 \mathrm{~m}$ (YankoHombach et al. 2011b).

It is difficult to reconstruct the lifeways of the Late Palaeolithic human population during this Late Neoeuxinian period due to the almost complete absence of large, long-term settlements, and consequently a scarcity of chronometric dates. For whatever reason, perhaps because of human overexploitation of the northern Black Sea steppe region, population density in this region appears to have sharply decreased, and in the DniesterBug interfluve, it became the lowest for the steppe zone within the modern territory of Ukraine (Yanko-Hombach et al. 2011a, Figure 6). As of now, only one ancient occupation-Vladimirovka (layer 3) — can be associated with any degree of certainty to the Late Neoeuxinian, and its technocomplex retains all the features typical of the Anetivka Late Palaeolithic culture (Chernysh 1953).

\subsubsection{Conditions of Preservation and Site Discovery}

Areas A and B seem never to have been submerged by transgression during the Late Pleistocene because neither the Tarkhankutian nor Late Neoeuxinian transgression exceeded the $30 \mathrm{~m}$ and $37 \mathrm{~m}$ isobath bsl, respectively. However, the transgressions would have caused an expansion of the river valleys, and this would have initiated meandering and steady infilling by fluvial sediments. In this way, the river valleys would have provided ample accommodation for sedimentary accumulation and buried settlements; i.e. any sites would have a good chance to be preserved.

Today, these areas are below sea level, however, and this means that they were inundated during the Holocene Mediterranean transgression. What are the chances that archaeological sites would have been preserved? There are two basic scenarios proposed for this transgression: progressive (Aksu et al. 2002) or progressive but oscillating (Balabanov 2007; Yanko-Hombach 2007; Yanko-Hombach et al. 2007) and catastrophic (Ryan 2007) or rapid (Nicholas et al. 2011; Lericolais 2017; Yanchilina et al. 2017).

In the case of a gradual transgression, there should be an upward succession of coarse to fine grained sediments. On the inner shelf, alluvial facies should be covered by marshy, estuarine and marine ones. Such a picture can be observed in Core 342 recovered from the Dniester palaeo-valley (Mudie et al. 2014; Yanko-Hombach et al. 2014). Over the course of a progressive transgression, the elevated watershed plateaux would have been prone to coastal abrasion and destroyed by the gradual sea-level rise. But the terraces and their associated protruding bluffs within the meanders of small rivers and tributaries would have been preserved, and these features, according to our data, are present in areas $\mathrm{A}$ and 
B. In the case of a gradual but oscillating scenario, low-amplitude sea-level fluctuations would be unlikely to destroy thick sequences of sediments or the settlements buried within them.

In the case of a catastrophic or rapid transgression, there would be sharp erosional downcutting in the river valleys, and this would destroy the bluffs and other elevated elements of relief together with the settlements buried within the sediments of previous transgressions. Such a picture of course is an ideal. In reality, it could be different.

In order to verify our predictive model and to improve the search for submerged Late Palaeolithic sites, an expedition 'Coast of Gods' was undertaken in 2012 with the participation of the first author and the use of a seine-fishing vessel 'MBSS 10-06' (Kerch registration port) and a scientific team to search for underwater prehistoric archaeological sites and materials on the Black Sea shelf. We used a remotely controlled submarine 'Sophocles-1' with a 'Towed Bottom Video, TBV-2', an underwater towing system (test model of the National Naval Construction University named after admiral Makarov, Nikolayev city) and sidescan sonar. Unfortunately, due to technical problems and harsh weather conditions, the expedition did not achieve its goal and was postponed pending acquisition of new funding.

\subsection{Conclusions}

Using on-land archaeological data on the locations of known Late Upper Palaeolithic sites, in a case study area located on the Dniester-Kuyalnik interfluve, we have analysed the main regularities in their spatial distribution. We found that all the sites examined are located on the lower alluvial terraces of smaller, tributary rivers and form small clusters, each of which includes two to four sites. The distribution of distances between the clusters of sites follows a normal (Gaussian) distribution with an average $19.49 \mathrm{~km}$ in walking distance between each cluster and its nearest neighbour.
We used geomorphological, geological and climatic data to identify the environmental factors determining the choice of site locations and to predict likely target areas for archaeological survey offshore on the now-submerged landscape. This predictive model identified two likely areas. The first area (A) is $9 \mathrm{~km}$ from the present coastline at water depths of $15-20 \mathrm{~m}$ in front of the present spit of the Dniester Estuary. Here there would have been small rivers flowing into the large palaeo-Dniester River, forming bluffs and terraces with good overviews of the surrounding terrain. The main elevation point is the Dniesterovsky Bank, which would have been a hill on the exposed land surface during the Late Palaeolithic. The area has outcrops of flint of good quality and quantity on the third alluvial terrace of the Dniester River, and according to our analysis, it is located at an appropriate distance from the nearest cluster of known sites in the present-day landscape. The second area (B) is located offshore from Sandzeika village, $7 \mathrm{~km}$ from the coastline at a water depth of 20-22 $\mathrm{m}$ on a river terrace of the Sukhoy palaeoriver, a tributary of the palaeo-Dnieper, with a good view to the other side of the river valley as well as towards its confluence with the palaeo-Dnieper valley. The distance of area B from other archaeological sites also fits the predictive model.

In the case of a gradual or gradual-butoscillating transgression by water from the Mediterranean at the Pleistocene-Holocene boundary, submerged archaeological sites should be preserved by being buried by thick fluvial sediments accumulated during the Late Pleistocene (Tarkhankutian and Late Neoeuxinian) transgressions. In the case of a catastrophic or rapid transgression, a sharp erosional downcutting within the river valleys would have destroyed the bluffs and other features of elevated relief together with any prehistoric settlements buried by sediments accumulated during previous transgressions.

Although the proposed model for finding submerged Late Palaeolithic archaeological sites on the north-western Black Sea shelf was not verified by successful underwater fieldwork, we identify the reasons for this failure not with the predictive model itself, but instead with techno- 
logical aspects of the fieldwork and the equipment used.

Taking into account the peculiarities of the region under study-depth below present sea level of around $30 \mathrm{~m}$, distance from the present seashore of about $10 \mathrm{~km}$, and most importantly the significant thickness of Holocene sediments-traditional underwater archaeology employing scuba-diving may not be effective for future survey. The only reliable source of information is a programme of underwater drilling, which will require substantial funding and the joint efforts of a multidisciplinary scientific team.

Acknowledgments We are grateful to Prof. Allan Gilbert from Fordham University, USA, for editing the English text and for valuable comments and to Geoff Bailey for his editorial suggestions and further work on the final text. This paper is a contribution to IGCP 521 'Black SeaMediterranean Corridor during the last $30 \mathrm{ky}$ : sea level change and human adaptation'; INQUA 0501 'CaspianBlack Sea-Mediterranean Corridor during the last $30 \mathrm{ka}$ : Sea-level change and human adaptive strategies'; IGCP 610 'From the Caspian to Mediterranean: Environmental Change and Human Response during the Quaternary'; the Russian-Ukrainian project No. $\Phi 28 / 428-2009$ 'The Northwestern Black Sea Region and Global Climate Change: Environmental Evolution during the last $20 \mathrm{ka}$ and Forecast for the 21st Century' sponsored by the State Fund for Fundamental Research, Ukraine; 'Theories on interaction between the environment and human society in the north-western Black Sea during the Late Pleistocene and Holocene' sponsored by the Ministry of Education and Science of Ukraine (2016-2018); INQUA Focus Group POCAS (SACCOM 1709F) 'Ponto-Caspian stratigraphy and geochronology' (2017-2020); and COST Action TD0902 SPLASHCOS project 'Submerged Prehistoric Archaeology and Landscapes of the Continental Shelf'.

In this paper, we have transliterated Cyrillic letters into the Latin alphabet according to the BGN/PCGN Romanization system for Russian used by Oxford University Press. Exceptions are the names of authors, which we have left in their own preferred transliterations, as well as geographical names as presented most commonly in the majority of English-language papers.

\section{References}

Abashin AA, Mel'nik VI, Sidenko OG (1982) Bottom morphology. Characteristics of relief. In: Shnyukov EF (ed) Geology of the Ukrainian shelf. Environment, history and methodology of the study. Naukova Dumka, Kiev, pp 82-88 (in Russian)
Aksu AE, Hiscott RN, Kaminski MA et al (2002) Last glacial-Holocene paleoceanography of the Black Sea and Marmara Sea: stable isotopic, foraminiferal and coccolith evidence. Mar Geol 190:119-149

Algan O, Yalçın MN, Özdoğan M, Yılmaz İ, Sarı E, Kırc1Elmas E, Ongan D, Bulkan-Yeşiladalı Ö, Yılmaz Y, Karamut İ (2009) A short note on the geoarchaeological significance of the ancient Theodosius Harbour (İstanbul-Turkey). Quat Res 72:457-461

Anikovich M, Anisutkin N, Vishnyatsty L (2007) Uzlovye problemy perekhoda $\mathrm{k}$ verkhnemu paleolitu Evrazii [Key points of transition to Late Paleolithic in Eurasia]. In: Platonova N (ed) Trudy Kostenkovsko-Borshcevskoy arheologicheskoy expeditsii v. 5 [Russian academy of science. The works of Kostenkovo-Borcevskiy archaeological expedition], vol 5. Nestor-Istoria, St. Petersburg, pp 203-211 (in Russian)

Artyushenko AT (1970) Rastitelnost' Lesostepi i Stepi Ukrainy $\mathrm{v}$ chetvertichnom periode [Vegetation of forest-steppe and steppe Ukraine in quaternary]. Naukova dumka, Kiev

Artyushenko AT, Pashkevich GA, Kareva EB (1972) Razvitie rastitel'nosti yuga Ukrainy v antropogene po dannym sporo-pyl'tsevogo analiza [Development of vegetation of the south of Ukraine in anthropogene]. Bull Comm Study Quat Period 39:82-89 (in Russian)

Avrametz VM, Kakaranza SD, Sibirchenko MG et al (2007) Zvit z provedennya geologichnoi ziomky masshtabu 1:200,000 pivnichno-zakhidnoi chastyny shelfu Chornogo morya v mezhakh arkushiv L-36XIII. -XIV, XV [report on geological survey 1:200,000 within quadrants L-36-XIII. L-36-XIV, L-36-XV]. Prichonomorske SRGE [Black Sea Area State Regional Geologic Enterprise], Odessa (in Ukrainian)

Bailey GN, Davidson I (1983) Site exploitation territory and topography: two case studies from Palaeolithic Spain. J Archaeol Sci 10:87-115

Balabanov IP (2007) Holocene sea-level changes of the Black Sea. In: Yanko-Hombach V, Gilbert AS, Panin N, Dolukhanov PM (eds) The Black Sea flood question: changes in coastline, climate and human settlement. Springer, Dordrecht, pp 711-730

Ballard RD (2001) Black Sea mysteries. Natl Geogr 199(5):52-69

Ballard RD, Hiebert FT, Coleman DF, Ward C, Smith JS, Willis K, Foley B, Croff K, Major C, Torre F (2001) Deepwater archaeology of the Black Sea: the 2000 season at Sinop, Turkey. Am J Archaeol 105:607-623

Blavatsky VD (1972) Submerged sectors of towns on the Black Sea coast. In: Underwater archaeology, a nascent discipline. UNESCO, Paris, pp 117-119

Bolikhovskaya N, Kaitamba M, Porotov A, Fouache E (2004) Environmental changes of the northeastern Black Sea's coastal region during the middle and late Holocene. In: Scott EM, Alekseev AY, Zaitseva $\mathrm{G}$ (eds) Impact of the environment on human migration in Eurasia, NATO science series IV: earth and environmental sciences, vol 42. Springer, Dordrecht, pp 209-223 
Bozilova E (1975) Correlation of the vegetational development and climatic changes in the Rila and Pirin mountains in the Late Glacial and Post Glacial time. In: Jordanov D, Bondev I, Kozuharov S, Kuzmanov B, Palamarev E (eds) Problems of Balkan flora and vegetation. Proceedings of the first international symposium on Balkan flora and vegetation, June 7-14, 1973. Varna Pensoft, Sofia, pp 64-71

Chabai VP (2007) The Middle Paleolithic and Early Upper Paleolithic in the northern Black Sea region. In: Yanko-Hombach V, Gilbert AS, Panin N, Dolukhanov PM (eds) The Black Sea flood question: changes in coastline, climate and human settlement. Springer, Dordrecht, pp 279-296

Chernysh FP (1953) Vladimirskaya paleoliticheskaya stoyanka [Vladimirskaya Paleolithic site]. Bull Comm Study Quat Period 17:43-51 (in Russian)

Coleman DF, Ballard RD (2007) Submerged paleoshorelines in the southern and western Black Sea - implications for inundated prehistoric archaeological sites. In: Yanko-Hombach V, Gilbert AS, Panin N, Dolukhanov PM (eds) The Black Sea flood question: changes in coastline, climate and human settlement. Springer, Dordrecht, pp 671-696

Demidenko Yu E (2000-2001) The European Early Aurignacian of Krems-Dufour type industries: a view from Eastern Europe. Préhistoire européenne 16-17:147-162

Dimitrov P, Dimitrov D (2004) The Black Sea, the flood, and the ancient myths. Slavena, Varna

Djindjian F, Sapozhnikov I, Stepanchuk V, Sapozhnikova G (2006) Upper Palaeolithic chronology, cultural facies and economic complexes of the northern Black Sea area. In: Torti JSS, Alcántara AMM, Fullole I, Pericot JM (eds) La Cuenca mediterránea durante el Paleolítico Superior 38.000-10.000 anès. IV Symposium de Prehistoria de la Cueva de Nerja. Fundacion Cueva de Nerja, Nerja, pp 46-59

Dodonov AE, Tchepalyga AL, Mihailescu CD, Zhou LP, Markova AK, Trubikhin VM, Simakova AN, Konikov EG (2000) Last-interglacial records from Central Asia to the northern Black Sea shoreline: stratigraphy and correlation. Geologie en Mijnbouw Netherlands Journal of Geosciences 79(2/3):303-311

Fedorov PV (1977) Pozdnechetvertichnaya istoriya Chernogo moria i razvitie yuzhnykh morey Evropy [Late quaternary history of the Black Sea and southern seas of Europe]. In: Kaplin PA, Shcherbakov FA (eds) Paleogeografiya i otlozheniya pleistotsena yuzhnykh morey SSSR [Paleogeography and deposits of the Pleistocene of the southern seas of the USSR]. Nauka, Moscow, pp 25-32 (in Russian)

Fedorov PV (1978) Pleistotsen Ponto-Kaspiya [The Pleistocene of the Ponto-Caspian]. Nauka, Moscow (in Russian)

Fedorov PV (1988) The problem of changes in the level of the Black Sea during the Pleistocene. Int Geol Rev 30:635-641

Gozhik PF (1984) Istoriya razvitiya limanov [History of the development of the limans]. In: Shnyukov EF (ed) Geologiya shel'fa USSR Limany [Geology of the Ukrainian Shelf Limans]. Naukova Dumka, Kiev, pp 76-80 (in Russian)

Gozhik PF, Karpov VA, Ivanov VG, Sibirchenko MG (1987) Golotsen severo-zapadnoy chasti Chernogo morya [Holocene of the northwestern part of the Black Sea]. Geologicheskiy Institut Ukrainskoy Akademii Nauk [Geological Institute of the Ukrainian Academy of Sciences]. Pre-Print 87-41 (in Russian)

Harff J, Bailey GN, Lüth F (2016) Geology and archaeology: submerged landscapes of the continental shelf: an introduction. In: Harff J, Bailey GN, Lüth F (eds) Geology and archaeology: submerged landscapes of the continental shelf. Geological Society, London, Special Publication 411, pp 1-8

Inozemtsev YI, Lutsiv YK, Sobotovich EV et al (1984) Holocene geochronology and facies complexes of the Pontic area. In: Shnyukov EF (ed) Izuchenie geologicheskoy istorii i protsessov sovremennogo osadkoobrazovaniya Chernogo i Baltiyskogo morey [Study of the geological history and processes of recent sedimentation in the Black and Baltic Seas]. Part 1. Naukova Dumka, Kiev, pp 103-113 (in Russian)

Ivanov VG (ed) (1987) Report on the development of stratigraphic scheme and legend of quaternary sediments of the Black Sea. Report of the Prichernomorskaya Expedition, Odessa (in Russian)

Karpov, VA, Ivanov, VG, Sibirchenko, MG et al. (1978) Otchet o geologicheskom izuchenii s s'emke Odesskogo zaliva Chernogo moria masshtaba 1:50,000 (List 36-51-A, C, G), 1976-1978 [Report of the Prichernomorskaya expedition on geological investigation and survey 1:50,000 within Odessa Bay of the Black Sea], Odessa (in Russian)

Kryzhitskiy SD, Rusyaiva AS, Krapivina VV, Leuipunskaya NA, Skrzhinskaya MV, Anokhin VA (1999) Olbia. Ancient State in the Northern Black Sea Region. Naukova dumka, Kiev (in Russian)

Kuprin PN (2002) Lithology and paleogeography of the Neoeuxinian (Late Pleistocene) stage of the Black Sea. Biulleten' Moskovskogo Obshchestva ispytatelei prirody. Otdel geologicheskiy [Bulletin of Moscow Society of Naturalists, Geological Branch] 77:59-69 (in Russian)

Kuprin PN, Sorokin VM (2007) On the postglacial changes in the level of the Black Sea. In: Yanko-Hombach V, Gilbert AS, Panin N, Dolukhanov PM (eds) The Black Sea flood question: changes in coastline, climate and human settlement. Springer, Dordrecht, pp 205-220

Kurten B (1969) Radiocarbon date for the cave bear remains (Ursus spelaeus) from Odessa. Soc Scient Fennica Comm Biolog 31:1-3

Kvasov DD (1975) Pozdnechetvertichnaya istoriya krupnykh ozer i vnutrennikh morey Vostochnoy Evropy [The Late Quaternary history of the large lakes and inland seas of Eastern Europe]. Nauka, Moscow (in Russian)

Larchenkov E, Kadurin S (2011) Paleogeography of the Pontic Lowland and northwestern Black Sea shelf for the past $25 \mathrm{ky}$. In: Buynevich I, Yanko-Hombach V, Gilbert A, Martin R (eds) Geology and geoarchaeology of the Black Sea region: beyond the flood hypoth- 
esis, Geological Society of America Special Paper 473. Geological Society of America, Colorado, pp 71-88

Lericolais G (2017) Late Pleistocene environmental factors defining the Black Sea, and submerged landscapes of the western continental shelf. In: Flemming NC, Harff J, Moura D, Burgess A, Bailey GN (eds) Submerged landscapes of the European continental shelf: quaternary paleoenvironments. Wiley, Chichester, pp 479-496

Marret F, Mudie P, Aksu A, Hiscott RN (2009) A Holocene dinocyst record of a two-step transformation of the Neoeuxinian brackish water lake into the Black Sea. Quat Int 193:72-86

Mudie PJ, Aksu AE, Yaşar D (2001) Late quaternary dinoflagellate cysts from the Black, Marmara and Aegean seas: variations in assemblages, morphology and paleosalinity. Mar Micropaleontol 43:155-178

Mudie PJ, Rochon A, Aksu AE (2002) Pollen stratigraphy of Late Quaternary cores from Marmara Sea: landsea correlation and paleoclimatic history. Mar Geol 190:233-260

Mudie PJ, Marret F, Aksu AE, Hiscott RN, Gillespie H (2007) Palynological evidence for climatic change, anthropogenic activity and outflow of Black Sea water during the Late Pleistocene and Holocene: centennialto decadal-scale records from the Black and Marmara Seas. Quat Int 167-168:73-90

Mudie PJ, Leroy SAG, Marret F et al (2011) Nonpollen palynomorphs: indicators of salinity and environmental change in the Caspian-Black Sea-Mediterranean corridor. In: Buynevich I, Yanko-Hombach V, Gilbert A, Martin R (eds) Geology and geoarchaeology of the Black Sea region: beyond the flood hypothesis, Geological Society of America special paper 473. Geological Society of America, Colorado, pp 245-262

Mudie PJ, Yanko-Hombach V, Kadurin S (2014) The Black Sea dating game and Holocene marine transgression. Open J Marine Sci 4:1-7

Nevesskaya LA (1965) Pozdnechetvertichnye dvustvorchatie mollyuski Chernogo moria, ikh sidtematica i ecologia [Late Quaternary Bivalve Molluscs of the Black Sea, their systematics and ecology]. Trudy Paleontologicheskogo Instituta Akademii Nauk SSSR [Proceedings of the Paleontologcal Institute of the USSR Academy of Sciences] 105. Nauka, Moscow, pp 1-39 (in Russian)

Nicholas WA, Chivas AR, Murray-Wallace CV, Fink D (2011) Prompt transgression and gradual salinisation of the Black Sea during the early Holocene constrained by amino acid racemization and radiocarbon dating. Quat Sci Rev 30:3769-3790

Otte M, Noiret P, López Bayón I (1997) Aspects of the Upper Palaeolithic in Central Europe. Préhistoire européenne 11:277-301

Peev PI (2009) The neolithisation of the Eastern Balkan Peninsula and fluctuations of the Black Sea level. Quat Int 197(1-2):87-92

Peychev V, Peev P (2006) Evolution of the Bulgarian Black Sea coast during the Holocene. Slavena, Varna (in Bulgarian)
Podoplelov ON, Karpov VA, Ivanov VG et al. (19731975) Otchet o geologicheskoi s'emki shelfa severozapadnoy chasti Chernogo moria masshtaba 1:50,000 [Report on geological survey 1:50,000 within northwestern part of the Black Sea]. Krymgeologya, Odessa (in Russian)

Pop I (1957) Palinologicheskie issledovaniya v Rumynii i ikh glavneyshie rezultaty [Palynological investigations in Romania and their main results]. Bot J 42(3):72-79

Ryan WBF (2007) Status of the Black Sea flood hypothesis. In: Yanko-Hombach V, Gilbert AS, Panin N, Dolukhanov PM (eds) The Black Sea flood question: changes in coastline, climate and human settlement. Springer, Dordrecht, pp 63-88

Samoilova TL (1988) Tira v VI-Ivv. do n.e. [Tyras in VI I centuries BC]. Naukova Dumka. Kiev (in Russian)

Sapozhnikov IV, Sapozhnikova GV (2011) Kamennyi vek Severo-Zapadnogo Prichernomoria. Stratum Plus 1:15-331 (in Russian)

Shcherbakov FA (1983) Materikovye okrainy v pozdnem pleistotsene i golotsene [Continental margins in the Late Pleistocene and Holocene]. Nauka, Moscow (in Russian)

Shcherbakov FA, Kuprin PN, Potapova LI et al (1978) Osadkonakoplenie na kontinental'noi okraine Chernogo moria [Sedimentation on the continental shelf of the Black Sea]. Nauka, Moscow (in Russian)

Shmuratko VI (2001) Gravitatsionno-rezonansnaiya ekzotektonika [Gravity-resonance exotectonic]. Astroprint, Odessa (in Russian)

Shnyukov EF (ed) (1985) Geologiya shel'fa USSR: Litologiya [Geology of Ukrainian shelf: lithology]. Naukova Dumka, Kiev (in Russian)

Sibirchenko MG, Karpov VA, Ivanov V et al. (1983) Otchet po izucheniyu litilogicheskogo sostava donnykh otlozheniy shelfa Chernogo morya s zeliyu sostavleniya geologolitologicheskoy karty masshtaba 1:200,000 [Report on Lithological Study of the Black Sea Shelf for the Preparation of Geological-Lithological Map 1:200,000]. Krymgeologia, Odessa (in Russian)

Sinitsyn AA, Praslov ND, Svezhencev YS, Sulerzhitskiy LD (1997) Radiouglerodnaya hronologia verhnego paleolita Vostochnoj Evropy. V. In: Sinitsyn AA, Praslov ND (eds) Radiouglerodnaya hronologia paleolita Vostochnoj Evropy i Severnoy Azii: Problemy i perspektivy. Akadem-Print, SanktPeterburg, pp 21-66 (in Russian)

Stanko VN (1997) Nekotorye itogi izucheniya pozdnego paleolita Severo-Zapadnogo Prichernomorya Yuzhnobugskaya gruppa pamyatnikov [Some results of investigations of the Late Paleolithic of NorthWestern Black Sea region 1 Southern Bug group of sites] In: Stanko VN (ed) Archeologiya i Etnologiya Vostochnoy Evropy. Materialy i issledovaniya [Archaeology and Ethnology of Eastern Europe. Materials and Investigations]. Hermes, Odessa, pp 14-27 (in Russian)

Stanko VN (1999) Anetovka 2 - pozdnepaleoliticheskoe poselenie I svyatilische ochotnikov na bizonov v Severnov Prichernomorie [Anetovka 2 - Late Paleolithic settlement and sacral place of bison hunt- 
ers in North Black Sea region]. Stratum Plus 1:322 (in Russian)

Stanko VN (2007) Fluctuations in the level of the Black Sea and Mesolithic settlement of the northern Pontic area. In: Yanko-Hombach V, Gilbert AS, Panin N, Dolukhanov PM (eds) The Black Sea flood question: changes in coastline, climate and human settlement. Springer, Dordrecht, pp 371-386

Svitoch AA, Selivanov AO, Yanina TA (1998) Paleogeographic events of the Ponto-Caspian and Mediterranean in Pleistocene: data on reconstruction and correlation. Moscow State University, Moscow (in Russian)

Veklich MF, Sirenko NA (1976) Pliotsen i pleistotsen levoberezhiya Nizhney Volgi i Krymskoy ravniny [Pliocene and Pleistocene of the left side of the Lower Dnieper and Crimean plain]. Naukova Dumka, Kiev (in Russian)

Veklich MF, Sirenko NA, Matviishina GN (1993) Stratigraficheskaya skhema chetvertichnikh otlozheniy Ukrainy [Stratigraphic scheme of the Ukrainian quaternary deposits]. Naukova Dumka, Kiev (in Russian)

Ward C, Ballard R (2004) Black Sea shipwreck survey 2000. Int J Naut Archaeol 33(1):2-13

Ward C, Horlings R (2008) The remote exploration and archaeological survey of four Byzantine ships in the Black Sea. In: Ballard R (ed) Archaeological oceanography. Princeton University Press, Princeton, pp $148-173$

Yanchilina AG, Ryan WBF, McManus F et al (2017) Compilation of geophysical, geochronological, and geochemical evidence indicates a rapid Mediterranean-derived submergence of the Black Sea's shelf and subsequent substantial salinification in the early Holocene. Mar Geol 383:14-34

Yanko-Hombach V (2007) Controversy over Noah's Flood in the Black Sea: geological and foraminiferal evidence from the shelf. In: Yanko-Hombach V, Gilbert AS, Panin N, Dolukhanov PM (eds) The Black Sea flood question: changes in coastline, climate and human settlement. Springer, Dordrecht, pp 149-204

Yanko-Hombach V (2017) Editorial to IGCP 610 special volume of Quaternary International. Quat Int 409:1-7

Yanko-Hombach V, Motnenko I (2016a) The Karangatian epoch in the Neopleistocene history of the Black Sea.
EGU General Assembly 2016, 17-22 April, Vienna, Austria, p 3152

Yanko-Hombach V, Motnenko I (2016b) The Karangatian epoch (MIS 5e) in the Black Sea basin. In: Gilbert A, Yanko-Hombach V (eds) Proceedings of IGCP 610 fourth plenary conference and field trip: "from the Caspian to Mediterranean: environmental change and human response during the quaternary", Tbilisi, Georgia, 1-9 October 2016, pp 202-206

Yanko-Hombach V, Smyntyna O (2009) Quaternary history of the Black Sea and adjacent regions: proceedings, IGCP 521-INQUA 0501 plenary meeting and field trip, Odessa, Ukraine. Quat Int 197:1-5

Yanko-Hombach V, Gilbert AS, Panin N, Dolukhanov PM (eds) (2007) The Black Sea flood question: changes in coastline, climate and human settlement. Springer, Dordrecht

Yanko-Hombach V, Smyntyna O, Kadurin SV et al (2011a) Black Sea level changes and adaptation strategies of prehistoric populations during the last $30 \mathrm{ka}$. Geologiya I mineral'nye resursy Mirovogo Okeana [Geol Miner Resour World Ocean] 2:61-94 (in Russian)

Yanko-Hombach V, Mudie P, Gilbert AS (2011b) Was the Black Sea catastrophically flooded during the post-glacial? Geological evidence and archaeological impacts. In: Benjamin J, Bonsall C, Pickard C, Fischer A (eds) Submerged prehistory. Oxbow Books, Oxford, pp 45-262

Yanko-Hombach V, Mudie PJ, Kadurin S, Larchenkov E (2014) Holocene marine transgression in the Black Sea: new evidence from the northwestern Black Sea shelf. Quat Int 345:100-118

Yanko-Hombach V, Schnyukov E, Pasynkov A, Sorokin V, Kuprin P, Maslakov N, Motnenko I, Smyntyna O (2017) Late Pleistocene-Holocene environmental factors defining the Azov-Black Sea basin, and the identification of potential sample areas for seabed prehistoric site prospecting and landscape exploration on the Black Sea continental shelf. In: Flemming NC, Harff J, Moura D, Burgess A, Bailey GN (eds) Submerged landscapes of the European continental shelf: quaternary paleoenvironments. Wiley, Chichester, pp 431-478

Zaliznyak L (2014) Paleolit Centralnoy Ukrainy [Paleolithic in Central Ukraine]. Ark Dent 3:3-17 (in Ukrainian)

Open Access This chapter is licensed under the terms of the Creative Commons Attribution 4.0 International License (http://creativecommons.org/licenses/by/4.0/), which permits use, sharing, adaptation, distribution and reproduction in any medium or format, as long as you give appropriate credit to the original author(s) and the source, provide a link to the Creative Commons licence and indicate if changes were made.

The images or other third party material in this chapter are included in the chapter's Creative Commons licence, unless indicated otherwise in a credit line to the material. If material is not included in the chapter's Creative Commons licence and your intended use is not permitted by statutory regulation or exceeds the permitted use, you will need to obtain permission directly from the copyright holder. 